\title{
Response of Net Photosynthetic Rate to Environmental Factors under Water Level Regulation in Paddy Field
}

\author{
Menghua Xiao', Yuanyuan $\mathrm{Li}^{2 *}$, Bin $\mathrm{Lu}^{3}$ \\ ${ }^{1}$ Zhejiang Institute of Hydraulics and Estuary, Hangzhou, China \\ ${ }^{2}$ North China University of Water Resources and Electric Power, School of Water Conservancy, Zhengzhou, China \\ ${ }^{3}$ Nanjing Hydraulic Research Institute, Nanjing, China
}

Received: 6 December 2017

Accepted: 2 January 2018

\begin{abstract}
Plant growth depends on soil and water environment of root and atmospheric environment of canopy. With the synergistic effect of environmental factors, it can affect the process of plant energy transportation, material interchange, and physiological accommodation. Aiming at two different micro-environments under flooding and drought condition in paddy field, this article conducted research on the net photosynthetic rate $\left(\mathrm{P}_{\mathrm{n}}\right)$ change law under water level regulation, and the relationship between $P_{n}$ and soil and water environment and atmospheric environmental factors. Results showed that $\mathrm{P}_{\mathrm{n}}$ descended in all growth stages under flooding or drought treatment. The descending range for lower leakage amount $(2 \mathrm{~mm} / \mathrm{d})$ was slightly higher than that for higher leakage amount $(4 \mathrm{~mm} / \mathrm{d})$, and it was slightly higher for heavy drought $(-600 \mathrm{~mm})$ with the comparison to light drought $(-400 \mathrm{~mm})$. $\mathrm{P}_{\mathrm{n}}$ exhibited an impact of quadric relationship on photosynthetic active radiation (PAR) and $\mathrm{CO}_{2}$ concentration $\left(\mathrm{C}_{\mathrm{i}}\right)$ - both in the morning and in the afternoon, while it exhibited an impact of quadric relationship on air temperature $\left(\mathrm{T}_{\mathrm{a}}\right)$ in the morning, and a linear relationship in the afternoon. It showed no obvious relationship on relative humidity $(\mathrm{RH})$ and vapor pressure deficit (VPD). With the comparison of two photosynthetic light response models under water-level regulation, it illustrated the flooding and drought conditions that resulted in $\mathrm{P}_{\mathrm{n}}$ decreasing according to the light suppression effect, while it showed the physiological compensation effect after rewatering. Additionally, the new photosyntheticlight response model fit better on the photosynthetic-light response curve than the non-rectangular hyperbolic model.
\end{abstract}

Keywords: net photosynthetic rate, water level regulation, environmental factors, photosynthetic light response model

*e-mail: liya66720@126.com 


\section{Introduction}

Rice irrigation area is an important carrier of regional ecological environment [1]. It involves regional economic development, social harmony and stability, improvement of ecological environment, and so on. However, there are still some problems in rice irrigation area, such as low efficiency of water and fertilizer utilization, and serious pollution of agricultural non-point sources, which restricts the sustainable development of the rice irrigation area $[2,3]$. With the development of the theory of crop irrigation and drainage, watersaving irrigation and controlled drainage technology attracted great attention both within China and abroad $[4,5]$. Agricultural water level is the depth of water layer after precipitation (or irrigation) and the depth of ground water level when there is no water layer. Water level regulation technique is crucial for water-saving irrigation drainage regulation, which is meaningful for water-saving pollution reduction and high rice yield in southern China [6-8].

As a major physiological process, photosynthesis provides energy and dry matter accumulation for plant growth. Also, the photosynthetic rate of rice leaves is related to final yield formation [9-11]. Water demand is different in different growth stages. On the one hand, the water deficit will make the leaf stomatal closure, photosynthetic product output slowed down; on the other hand, excessive soil moisture will make soil ventilation in poor conditions and produce secondary stress, resulting in decreased crop root vigor, indirectly affecting photosynthesis $[12,13]$. Since the physiological indicators (leaf water potential, transpiration rate, stomatal conductance, $\mathrm{P}_{\mathrm{n}}$, chlorophyll fluorescence parameters, etc.) are sensitive to water, higher or lower water levels could result in changes to the physiological process $[14,15]$. $\mathrm{Li}[16]$ found that water-logging stress in the late growth stage resulted in decreasing $\mathrm{P}_{\mathrm{n}}$, green leaves number of the main stem, and thousand-grain weight. Hirano [17] found that after water-logging, the transportation of carbon to the top internodes was promoted by adjusting the distribution of photosynthetic products to promote the growth of rice plant internodes. However, in reproductive growth stage, much more dry matter could be accumulated for light water-logging plants, thus the final plant production was promoted. $\mathrm{Hu}$ [18] found that under drought stress conditions, $\mathrm{P}_{\mathrm{n}}$ was decreasing, and it decreased slowly with light water stress, while it decreased rapidly until water stress reached a certain level. However, Lv [19] found that moderate water deficit will not bring out the result of obvious photosynthetic rate descending. Ming [20] carried out the experiments with different concentrations of polyethylene glycol (PEG6000) to simulate drought. Results showed that with $10 \%$ PEG treatment, $\mathrm{P}_{n}$ decreased obviously, while stomatal conductance and leaf $\mathrm{CO}_{2}$ concentration increased; with $15 \%$ PEG treatment, $\mathrm{P}_{\mathrm{n}}$ kept decreasing; also, it decreased with stomatal conductance and leaf $\mathrm{CO}_{2}$ concentration decreasing.

The physiological response of rice with water-saving irrigation was based mostly on a single irrigation or drainage. Water depth was considered the irrigation upper limit, while the soil moisture in root zone irrigation was considered the lower limit. However, in the actual application, the soil moisture spatial variability is not easy to grasp [21, 22]. The problem of irrigation and drainage of rice is actually how to control the change of water level in farmland, that is the regulation of farmland water level [23]. At the field scale, the spatial variability of farmland water level is very small and easy to observe. So, taking water level regulation into consideration, this article carried out research on the response of $\mathrm{P}_{\mathrm{n}}$ to environmental factors on the basis of the change of $\mathrm{P}_{\mathrm{n}}$. It was valuable for improving field water use efficiency and efficient agriculture.

\section{Materials and Methods}

\section{Experimental Site}

This study was carried out at the saving water and agro-ecological experimental plot in 2011 and 2012, Key Laboratory of Efficient Irrigation-Drainage and Agricultural Soil-Water Environment in Southern China, Ministry of Education (latitude $31^{\circ} 55^{\prime} \mathrm{N}$, longitude $\left.118^{\circ} 46^{\prime} \mathrm{E}\right)$. The region has a subtropical humid monsoon climate zone, with an average annual evaporation of $900 \mathrm{~mm}$, yearly average temperature of $15.4^{\circ} \mathrm{C}$, and maximum and minimum air temperatures of $43.0^{\circ} \mathrm{C}$ and $-14.0^{\circ} \mathrm{C}$, respectively. Mean annual rainfall is $1,041 \mathrm{~mm}$, of which more than $60 \%$ of precipitation happens in the rainy season (namely from May to September), and there are 220 frost-free days per year. The soil in the area is atypical permeable paddy soil formed on the loess deposits, with loamy clay. The area adopts a five-year rice-wheat rotation system. There are 32 fixed lysimeter plots (28 with closed bottom and 4 without) with specifications of $2.5 \mathrm{~m}$ length, $2 \mathrm{~m}$ width, and $2 \mathrm{~m}$ depth. The lysimeter layout is divided into two groups, with each group containing 16 plots. The underground corridors and underground equipment rooms are built between the two groups and the mobile canopy is equipped on the ground. The irrigation system is an automatic irrigation system controlled by the host-electromagnetic valve (Fig. 1). The topsoil $(0-30 \mathrm{~cm})$ with $\mathrm{pH}$ value of 6.97 in lysimeter contained $2.40 \%$ soil organic matter, $0.9048 \mathrm{~g} \mathrm{~kg}^{-1}$ total nitrogen, $27.65 \mathrm{mg} \mathrm{kg} \mathrm{m}^{-1}$ available nitrogen, $0.32 \mathrm{~g} \mathrm{~kg}^{-1}$ total phosphorus, and $12.5 \mathrm{mg} \mathrm{kg}^{-1}$ available phosphorus.

\section{Experimental Design}

Paddy rice (Oriza sativa L. cv. Yang 4038) was grown under two leakage intensity $\left(2 \mathrm{~mm} \mathrm{~d}^{-1}\right.$ and 


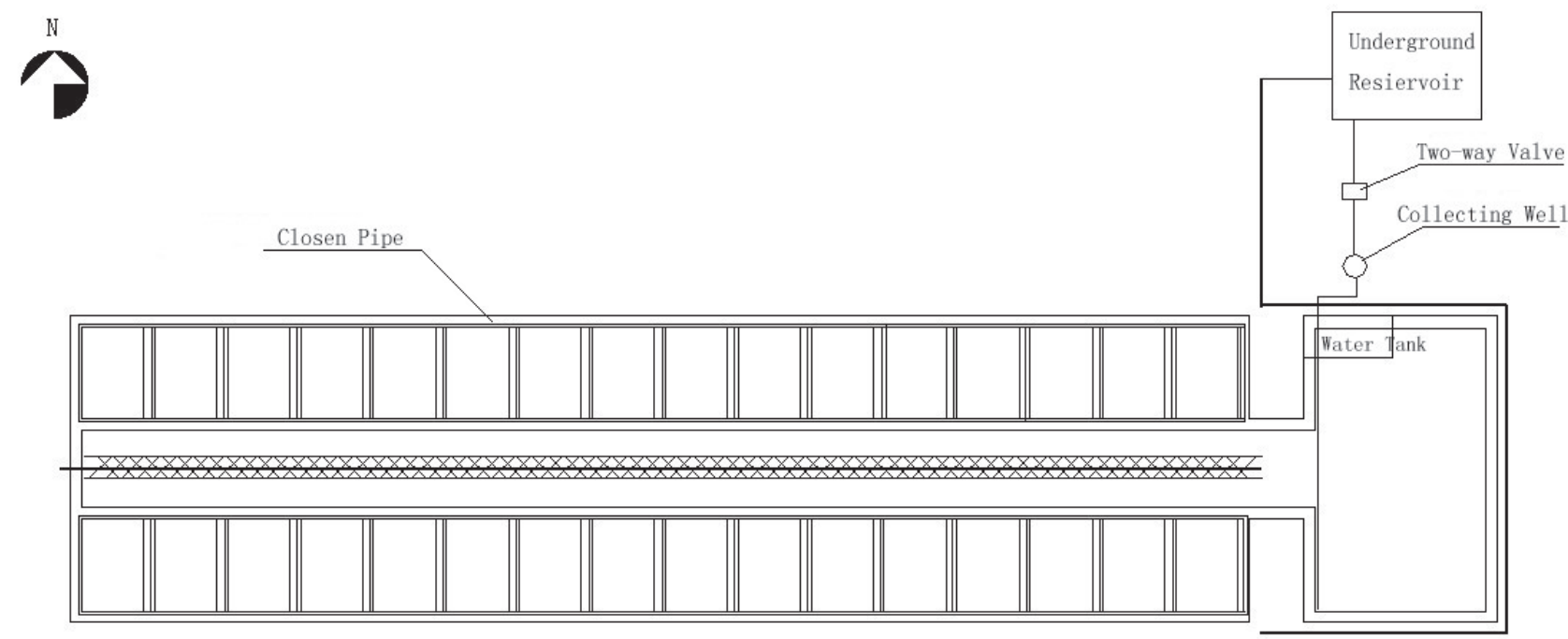

Fig. 1. Layout of the study area and experimental management.

Table 1. Water level regulation scheme and water control stages division in 2011.

\begin{tabular}{|c|c|c|c|c|c|c|}
\hline \multirow{2}{*}{\multicolumn{2}{|c|}{ Treatments }} & Tillering stage & Jointing-booting stage & Heading-flowering stage & Milky stage & \multirow{2}{*}{$\begin{array}{l}\text { Starting and } \\
\text { ending time }\end{array}$} \\
\hline & & \multirow{2}{*}{$\begin{array}{c}(07.05 \sim 08.05) \\
\mathbf{1 2 0} \mathbf{m m} / \mathbf{2} \mathbf{m m} / \mathbf{d}\end{array}$} & $(08.06 \sim 08.26)$ & $(08.27 \sim 09.09)$ & (09.10 10.10) & \\
\hline \multirow{8}{*}{$\begin{array}{c}\text { Water } \\
\text { flooding }\end{array}$} & L1 & & $-300 \sim 30 \mathrm{~mm}$ & $-300 \sim 30 \mathrm{~mm}$ & $300 \sim 30 \mathrm{~mm}$ & \multirow{2}{*}{$07.19 \sim 07.28$} \\
\hline & L2 & $120 \mathrm{~mm} / 4 \mathrm{~mm} / \mathrm{d}$ & $-300 \sim 30 \mathrm{~mm}$ & $-300 \sim 30 \mathrm{~mm}$ & $300 \sim 30 \mathrm{~mm}$ & \\
\hline & L3 & $-200 \sim 20 \mathrm{~mm}$ & $250 \mathrm{~mm} / 2 \mathrm{~mm} / \mathrm{d}$ & $-300 \sim 30 \mathrm{~mm}$ & $300 \sim 30 \mathrm{~mm}$ & \multirow{2}{*}{$08.14 \sim 08.23$} \\
\hline & L4 & $-200 \sim 20 \mathrm{~mm}$ & $250 \mathrm{~mm} / 4 \mathrm{~mm} / \mathrm{d}$ & $-300 \sim 30 \mathrm{~mm}$ & $300 \sim 30 \mathrm{~mm}$ & \\
\hline & L5 & $-200 \sim 20 \mathrm{~mm}$ & $-300 \sim 30 \mathrm{~mm}$ & $250 \mathrm{~mm} / 2 \mathrm{~mm} / \mathrm{d}$ & $300 \sim 30 \mathrm{~mm}$ & \multirow{2}{*}{$08.30 \sim 09.08$} \\
\hline & L6 & $-200 \sim 20 \mathrm{~mm}$ & $-300 \sim 30 \mathrm{~mm}$ & $250 \mathrm{~mm} / 4 \mathrm{~mm} / \mathrm{d}$ & $300 \sim 30 \mathrm{~mm}$ & \\
\hline & L7 & $-200 \sim 20 \mathrm{~mm}$ & $-300 \sim 30 \mathrm{~mm}$ & $-300 \sim 30 \mathrm{~mm}$ & $250 \mathrm{~mm} / 2 \mathrm{~mm} / \mathrm{d}$ & \multirow{2}{*}{$09.12 \sim 09.21$} \\
\hline & L8 & $-200 \sim 20 \mathrm{~mm}$ & $-300 \sim 30 \mathrm{~mm}$ & $-300 \sim 30 \mathrm{~mm}$ & $250 \mathrm{~mm} / 2 \mathrm{~mm} / \mathrm{d}$ & \\
\hline \multirow{8}{*}{$\begin{array}{c}\text { Water } \\
\text { droughting }\end{array}$} & H1 & $-300 \mathrm{~mm}$ & $-300 \sim 30 \mathrm{~mm}$ & $-300 \sim 30 \mathrm{~mm}$ & $-300 \sim 30 \mathrm{~mm}$ & \multirow{2}{*}{$07.19 \sim$} \\
\hline & $\mathrm{H} 2$ & $-500 \mathrm{~mm}$ & $-300 \sim 30 \mathrm{~mm}$ & $-300 \sim 30 \mathrm{~mm}$ & $-300 \sim 30 \mathrm{~mm}$ & \\
\hline & H3 & $-200 \sim 20 \mathrm{~mm}$ & $-400 \mathrm{~mm}$ & $-300 \sim 30 \mathrm{~mm}$ & $-300 \sim 30 \mathrm{~mm}$ & \multirow{2}{*}{$08.14 \sim$} \\
\hline & $\mathrm{H} 4$ & $-200 \sim 20 \mathrm{~mm}$ & $-600 \mathrm{~mm}$ & $-300 \sim 30 \mathrm{~mm}$ & $-300 \sim 30 \mathrm{~mm}$ & \\
\hline & H5 & $-200 \sim 20 \mathrm{~mm}$ & $--300 \sim 30 \mathrm{~mm}$ & $-400 \mathrm{~mm}$ & $-300 \sim 30 \mathrm{~mm}$ & \multirow{2}{*}{$08.30 \sim$} \\
\hline & H6 & $-200 \sim 20 \mathrm{~mm}$ & $-300 \sim 30 \mathrm{~mm}$ & $-600 \mathrm{~mm}$ & $-300 \sim 30 \mathrm{~mm}$ & \\
\hline & H7 & $-200 \sim 20 \mathrm{~mm}$ & $-300 \sim 30 \mathrm{~mm}$ & $-300 \sim 30 \mathrm{~mm}$ & $-400 \mathrm{~mm}$ & \multirow{2}{*}{$09.12 \sim$} \\
\hline & H8 & $-200 \sim 20 \mathrm{~mm}$ & $--300 \sim 30 \mathrm{~mm}$ & $-300 \sim 30 \mathrm{~mm}$ & $-600 \mathrm{~mm}$ & \\
\hline $\begin{array}{l}\text { Contrast } \\
\text { treatment }\end{array}$ & CK & $-300 \sim 30 \mathrm{~mm}$ & $-300 \sim 30 \mathrm{~mm}$ & $-300 \sim 30 \mathrm{~mm}$ & $-300 \sim 30 \mathrm{~mm}$ & \\
\hline
\end{tabular}

Note:(1) During the water control period, water level and time was controlled according to table1.After that, water level was recovered to reasonable upper water level limit. (2) Water flooding test lasted 10 days, and it was controlled according to set leakage amount. At other stages, the leakage amount was set at $2 \mathrm{~mm} \mathrm{~d}^{-1}$ when there was a water layer, while it was o when there was no water layer. During water control stage, there was no water supplement when water table decreasing. (3) Starting time for water flooding and water droughting in each growing stage was same. As for water droughting test, it was from no water layer decreasing to the set value. According to the water controlling days, once to twice drought was carried out in each growing stage. 
$4 \mathrm{~mm} \mathrm{~d}^{-1}$ ) and two groundwater tables during the growth stages (Table 1). The rice seed was soaked at 09:00 on 15 May and germinated at 10:00 on 17 May, then it was seedling on 19 May and transplanted on 29 June. It was at the 8-leaf stage when transplanted, and the planting density was $25 \times 15 \mathrm{~cm}$, with a total of $8 \times 10^{5}$ seedlings per $\mathrm{hm}^{2}$.

\section{Experimental Materials and Methods}

The paddy field was irrigated and drained according to the experimental scheme in Table 1, and water amount of irrigation and drainage was recorded. For the measuring plot and soil column treatments, 4 seedlings and 3 seedlings were tagged respectively in each growth stage for measuring $\mathrm{P}_{\mathrm{n}}$. The measuring time was 10:00 to $14: 00$, and the time interval was as follows: once before water control, once during water control, and 2-3 times after the water level returned to

a)

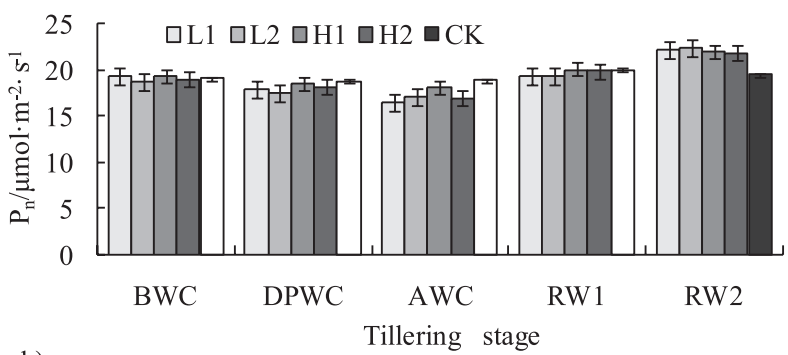

b)

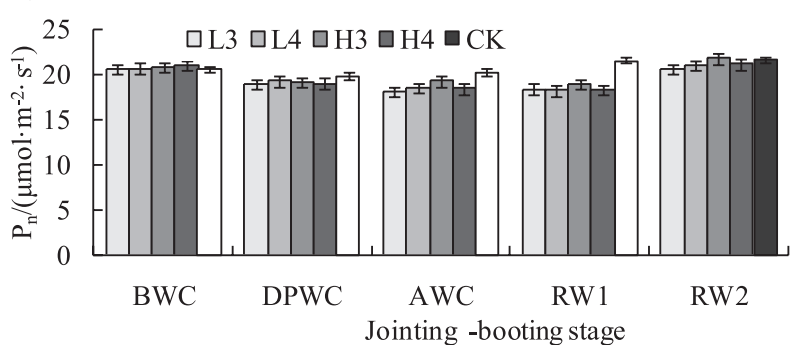

c)

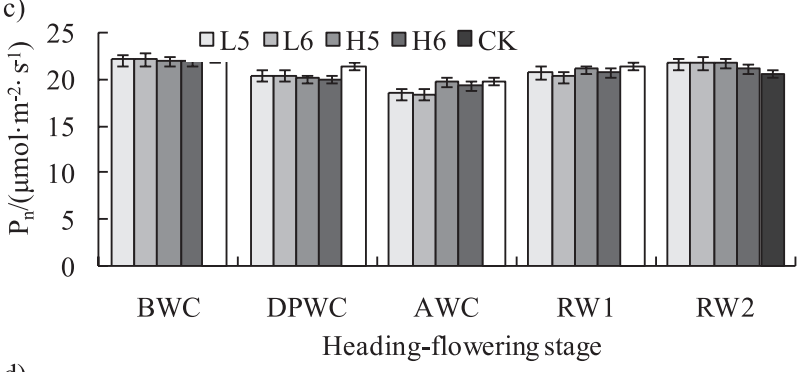

d)

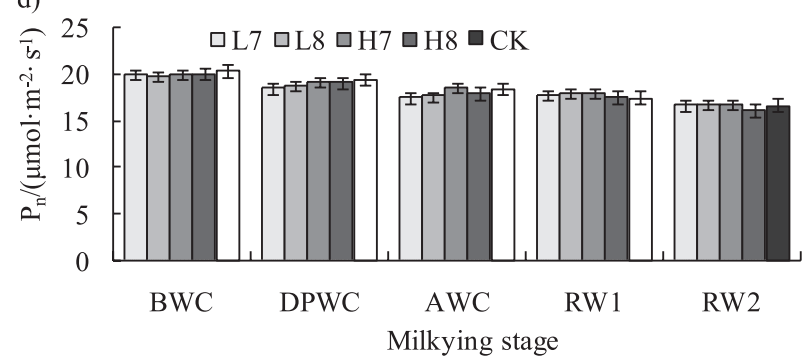

Fig. 2. Dynamic change of net photosynthetics. normal. Photosynthetic parameters were measured by a portable photosynthesis system (Li-6400) and LED red/ blue light source (LI-COR, USA). The environmental factors (light intensity, temperature, and humidity) were also recorded.

\section{Statistical Snalysis}

Simple data calculation and diagramming was completed by Excel 2010. Correlation analysis and regression analysis was carried out by IBM SPSS Statistics 19. Nonlinear model parameters solution and statistical analysis was conducted by MATLAB 7.0 and $1^{\text {st }}$ Opt 1.5 .

\section{Results and Discussion}

\section{Dynamic Change of Net Photosynthetic Rate under Paddy Field Water Level Regulation}

From Fig. 2 it was clear that $\mathrm{P}_{\mathrm{n}}$ was decreasing both under the flooding and drought treatments, and the decreasing degree was increasing with the water controlling time increasing. The $\mathrm{P}_{n}$ descending degree at the leakage level of $2 \mathrm{~mm} / \mathrm{d}$ was higher than that at the leakage level of $4 \mathrm{~mm} / \mathrm{d}$. The greater the degree of drought, the greater the $\mathrm{P}_{\mathrm{n}}$ decline. At the tillering stage, it showed a compensation effect after for about 7-8 days, while at the jointing-booting and heading-flowering stages it returned to the control level after rewatering for about 7-8 days, and at the milky stage it returned to the control level after rewatering for about 3-4 days. The descending order of accumulated $\mathrm{P}_{\mathrm{n}}$ value $\left(\sum P_{n(10: 00)}\right)$ was: $\mathrm{H} 1>\mathrm{CK}>\mathrm{H} 2>\mathrm{L} 1>\mathrm{L} 2$ (tillering stage); $\mathrm{CK}>\mathrm{H} 3>\mathrm{H} 4>\mathrm{L} 4>\mathrm{L} 3$ (jointing-booting stage); $\mathrm{CK}$ $>\mathrm{H} 5>\mathrm{L} 5>\mathrm{H} 6>\mathrm{L} 6$ (heading-flowering stage); and $\mathrm{CK}>\mathrm{H} 7>\mathrm{L} 8>\mathrm{H} 8>\mathrm{L} 7$ (milky stage). Zhu [24] found that there was an obvious interaction to photosynthetic productivity, dry matter accumulation on paddy field drainage degree, and canopy apparent photosynthetic rate at 15 days and 30 days was decreased, but returned after rewatering, which accorded with our study. Chaum [25] found that Glybet pre-treated plants maintained a high level of $\mathrm{P}_{\mathrm{n}}$ even under $25 \%$ soil water content, which illustrated that light drought had a slight effect on $\mathrm{P}_{\mathrm{n}}$ value, which was in accordance with our study results.

\section{Response of $\mathrm{P}_{\mathrm{n}}$ to Environmental Factors under Paddy Field Water Level Regulations}

As shown in Fig. 3, the net $\mathrm{P}_{\mathrm{n}}$ value in the morning was higher than that in the afternoon under the same PAR. Compared to flooding treatment, the $P_{n}$ value decreased obviously in the morning for drought treatment, reaching the peak value at the PAR of around $900 \mu \mathrm{mol} \cdot \mathrm{m}^{-2} \cdot \mathrm{mol}^{-1}$. At noon, the PAR value concentrated in the range of $900-1800 \mu \mathrm{mol} \cdot \mathrm{m}^{-2} \cdot \mathrm{mol}^{-1}$ for both flooding 
and drought treatments. Also, the change of $\mathrm{P}_{n}$ value for flooding treatment $\left(10-25 \mu \mathrm{mol} \cdot \mathrm{m}^{-2} \cdot \mathrm{mol}^{-1}\right)$ was greater than that for drought treatment $\left(15-25 \mu \mathrm{mol} \cdot \mathrm{m}^{-2} \cdot \mathrm{mol}^{-1}\right)$. $\mathrm{T}_{\mathrm{a}}$ is a major factor for photosynthesis process, and the physical exchange of $\mathrm{CO}_{2}$ and water vapor between leaves and air. It could also affect the $\mathrm{P}_{\mathrm{n}}$ level according to the effect on enzyme activity. The $\mathrm{P}_{n}$ value reached
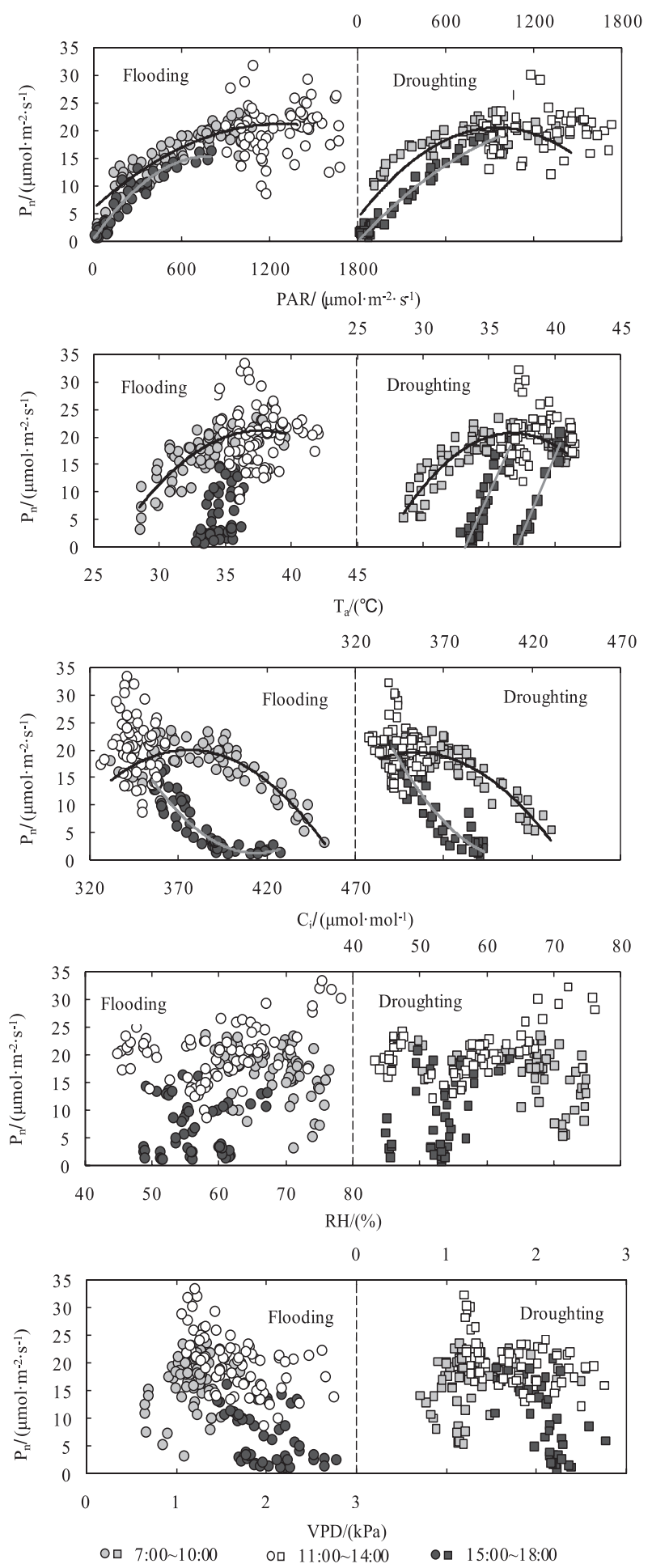

Fig. 3. Response of $P_{n}$ to environmental factors under paddy field water level regulation. the peak at temperatures of $37^{\circ} \mathrm{C}$ and $35^{\circ} \mathrm{C}$, respectively, for flooding and drought treatments in the morning. The $\mathrm{T}_{\mathrm{a}}$ at noon ranged from $35^{\circ} \mathrm{C}$ to $42^{\circ} \mathrm{C}$, and the $\mathrm{P}_{\mathrm{n}}$ ranged from $15 \mu \mathrm{mol} \cdot \mathrm{m}^{-2} \cdot \mathrm{mol}^{-1}$ to $35 \mu \mathrm{mol} \cdot \mathrm{m}^{-2} \cdot \mathrm{mol}^{-1}$. The $\mathrm{P}_{\mathrm{n}}$ in the afternoon was lower than that in the morning under the same $\mathrm{T}_{\mathrm{a}} \cdot \mathrm{CO}_{2}$ is the raw material for photosynthesis. The concentration change of $\mathrm{CO}_{2}$ in the air could affect the $\mathrm{CO}_{2}$ concentration $\left(\mathrm{C}_{\mathrm{i}}\right)$ among leaf cells. The $\mathrm{P}_{\mathrm{n}}$ values for flooding and drought treatments reached the peak in the morning, when the $\mathrm{C}_{\mathrm{i}}$ levels were $380 \mu \mathrm{mol} \cdot \mathrm{mol}^{-1}$ and $350 \mu \mathrm{mol} \cdot \mathrm{mol}^{-1}$, respectively. When the $\mathrm{C}_{\mathrm{i}}$ ranged from $330 \mu \mathrm{mol} \cdot \mathrm{mol}^{-1}$ to $360 \mu \mathrm{mol} \cdot \mathrm{mol}^{-1}$ at noon, the $\mathrm{P}_{\mathrm{n}}$ value ranged from $15 \mu \mathrm{mol} \cdot \mathrm{m}^{-2} \cdot \mathrm{mol}^{-1}$ to $35 \mu \mathrm{mol} \cdot \mathrm{m}^{-2} \cdot \mathrm{mol}^{-1}$. At the same leaf $\mathrm{C}_{\mathrm{i}}$, the $\mathrm{P}_{\mathrm{n}}$ value in the afternoon was lower than that in the morning, which showed the hysteresis of photosynthetic rate on $\mathrm{CO}_{2}$ concentration. $\mathrm{RH}$ and VPD could affect the photosynthetic rate according to the effect on stomatal conductance and transpiration rate. As shown in Fig. 2, the $\mathrm{P}_{\mathrm{n}}$ change trend was not clear at the three periods, however, the distribution area of scatter points is obviously divided in each time interval. Xia [26] found that PAR was the most important ecological factor affecting $\mathrm{P}_{\mathrm{n}}$, followed by air $\mathrm{CO}_{2}$ concentration, and with the intensification of water stress the $T_{a}$ evidently restrained $P_{n}$ by using path analysis. The relative water content (RWC) regimes were different than our study.

\section{Correlation Analysis on $\mathrm{P}_{\mathrm{n}}$ and Environmental Factors under Water Level Regulation}

From Table 2, for both flooding and drought treatments, at the time period of 07:00-10:00 and 15:00-18:00, $P_{n}$ exhibited an impact of quadric relationship on PAR. At the time period of 07:00-10:00, 11:00-14:00, and 15:00-18:00, $\mathrm{P}_{\mathrm{n}}$ exhibited an impact of quadric relationship on $\mathrm{T}_{\mathrm{a}}$ in the morning, while it showed a linear relationship in the afternoon. Moreover, $\mathrm{P}_{\mathrm{n}}$ exhibit an impact of quadric relationship on $\mathrm{C}_{\mathrm{i}}$ both in the morning and in the afternoon.

\section{Modeling on Photosynthetic-Light Response under Different Paddy Field Water Level Regulation}

Traditional photosynthetic-light response model is a non-rectangular hyperbolic model proposed by Herrick [27] and based on the kinetic principle of enzymatic reaction, as follows:

$\theta \cdot P^{2}-P\left(\alpha \cdot P P F D+P_{\max }\right)+\alpha \cdot P P F D \cdot P_{\max }=0$

...where $P$ is total photosynthetic rate, $\mu \mathrm{mol} \cdot \mathrm{m}^{-2} \cdot \mathrm{s}^{-1} ; \theta$ is convexity of non-rectangular hyperbola; and PPFD is photosynthetically effective quantum flux density, $\mu \mathrm{mol} \cdot \mathrm{m}^{-2} \cdot \mathrm{s}^{-1}$. When $\theta=0$, the non-rectangular hyperbola convert to rectangular hyperbola. When $\theta \neq 0$, since $P_{n}=P-R_{d}$, the above formula (1) could convert to the following formula (2): 
Table 2. Relationship between $\mathrm{P}_{\mathrm{n}}$ and environmental factors in different time periods.

\begin{tabular}{|c|c|c|c|c|c|c|}
\hline Relationship & Treatment & Time Period & Fitting Equation & $\mathrm{R}^{2}$ & $\mathrm{~F}$ & $\mathrm{p}$ \\
\hline \multirow{4}{*}{$\begin{array}{c}\mathrm{P}_{\mathrm{n}} \\
\text { and PAR }\end{array}$} & \multirow{2}{*}{ Flooding } & am & $y=-9 E-06 x^{2}+0.0240 x+5.9349$ & 0.8053 & 142.733 & $<0.001$ \\
\hline & & $\mathrm{pm}$ & $y=-3 E-05 x^{2}+0.0426 x+0.0023$ & 0.9101 & 280.226 & $<0.001$ \\
\hline & \multirow{2}{*}{ Drought } & am & $y=-2 E-05 x^{2}+0.0346 x+4.0830$ & 0.8302 & 149.140 & $<0.001$ \\
\hline & & $\mathrm{pm}$ & $y=-9 E-06 x^{2}+0.0287 x-0.1358$ & 0.9684 & 643.306 & $<0.001$ \\
\hline \multirow{4}{*}{$\begin{array}{c}\mathrm{P}_{\mathrm{n}} \\
\text { and } \mathrm{T}_{\mathrm{a}}\end{array}$} & \multirow{2}{*}{ Flooding } & am & $y=-0.1648 x^{2}+12.414 x-212.73$ & 0.7026 & 81.496 & $<0.001$ \\
\hline & & $\mathrm{pm}$ & $y=2.4912 x-80.012$ & 0.3081 & 22.260 & $<0.001$ \\
\hline & \multirow{2}{*}{ Drought } & am & $y=-0.2178 x^{2}+16.019 x-273.79$ & 0.8019 & 123.476 & $<0.001$ \\
\hline & & $\mathrm{pm}$ & $y=5.2912 x-175.71$ & 0.8410 & 163.999 & $<0.001$ \\
\hline \multirow{4}{*}{$\begin{array}{c}\mathrm{P}_{\mathrm{n}} \\
\text { and } \mathrm{Ci}\end{array}$} & \multirow{2}{*}{ Flooding } & am & $y=-0.0029 x^{2}+2.1674 x-387.24$ & 0.7322 & 94.308 & $<0.001$ \\
\hline & & $\mathrm{pm}$ & $y=0.0039 x^{2}-3.2062 x+665.26$ & 0.8504 & 139.257 & $<0.001$ \\
\hline & \multirow{2}{*}{ Drought } & am & $y=-0.0028 x^{2}+1.9558 x-326.94$ & 0.8036 & 124.807 & $<0.001$ \\
\hline & & $\mathrm{pm}$ & $y=0.004 x^{2}-3.3269 x+683.67$ & 0.8392 & 109.567 & $<0.001$ \\
\hline
\end{tabular}

$P_{n}=\frac{\alpha \cdot P P F D+P_{\max }-\sqrt{\left(\alpha \cdot P P F D+P_{\max }\right)^{2}-4 \theta \cdot \alpha \cdot P P F D \cdot P_{\max }}}{2 \theta}-R_{d}$

When the light response curve is expressed by the non-rectangular hyperbolic model, it is an asymptote line. In the actual application process, the saturation light intensity may be much lower than the actual measured value, and maximum photosynthetic rate may be much greater than the measured value; also, the data under the condition of light suppression cannot be dealt with. Ye [28] improved a new model against the above issue, as shown in the following formula (3),

$$
P_{n}=\alpha \frac{1-\cdot I}{1+\gamma \cdot I} \cdot I-R_{d}
$$

...where $P_{n}$ is net photosynthetic rate, $\mu \mathrm{mol} \cdot \mathrm{m}^{-2} \cdot \mathrm{s}^{-1} ; I$ is photosynthetic active radiation, $\mu \mathrm{mol} \cdot \mathrm{m}^{-2} \cdot \mathrm{s}^{-1} ; R_{d}$ is dark respiration rate, $\mu \mathrm{mol} \cdot \mathrm{m}^{-2} \cdot \mathrm{s}^{-1} ; \alpha$ is initial slope of light response curve $(I=0) ; \beta$ is the correction coefficient; and $\gamma$ is the ration of initial slope to the maximum photosynthetic rate of light response curve $\left(\gamma=\alpha / P_{\max }\right)$.

In this study, two models were adopted to simulate the photosynthetic light response curve for flooding and control treatments at joint-booting stage, and the results are shown in Fig. 4, Table 3, and Table 4. This illustrated that the $P_{n}$ value was increasing then decreasing with the increasing light intensity under the flooding treatment, which showed obvious light suppression phenomenon, while there was no obvious light suppression under control treatment. When PAR $<800 \mu \mathrm{mol} \cdot \mathrm{m}^{-2} \cdot \mathrm{mol}^{-1}$, the change trends for two treatments were consistent; when $\mathrm{PRA}=1000 \mu \mathrm{mol} \cdot \mathrm{m}^{-2} \cdot \mathrm{mol}^{-1}$, the $\mathrm{P}_{\mathrm{n}}$ reached the saturation under flooding treatment; $\mathrm{P}_{\mathrm{n}}$ decreased rapidly when PRA $>1000 \mu \mathrm{mol} \cdot \mathrm{m}^{-2} \cdot \mathrm{mol}^{-1}$, which illustrated that the light suppression of rice leaves was aggravated under the waterlogging stress, resulting in $\mathrm{P}_{\mathrm{n}}$ decreasing under strong light conditions. As for the non-rectangular hyperbolic model, it fit better for the light response curve with no light suppression, while it fit worse for
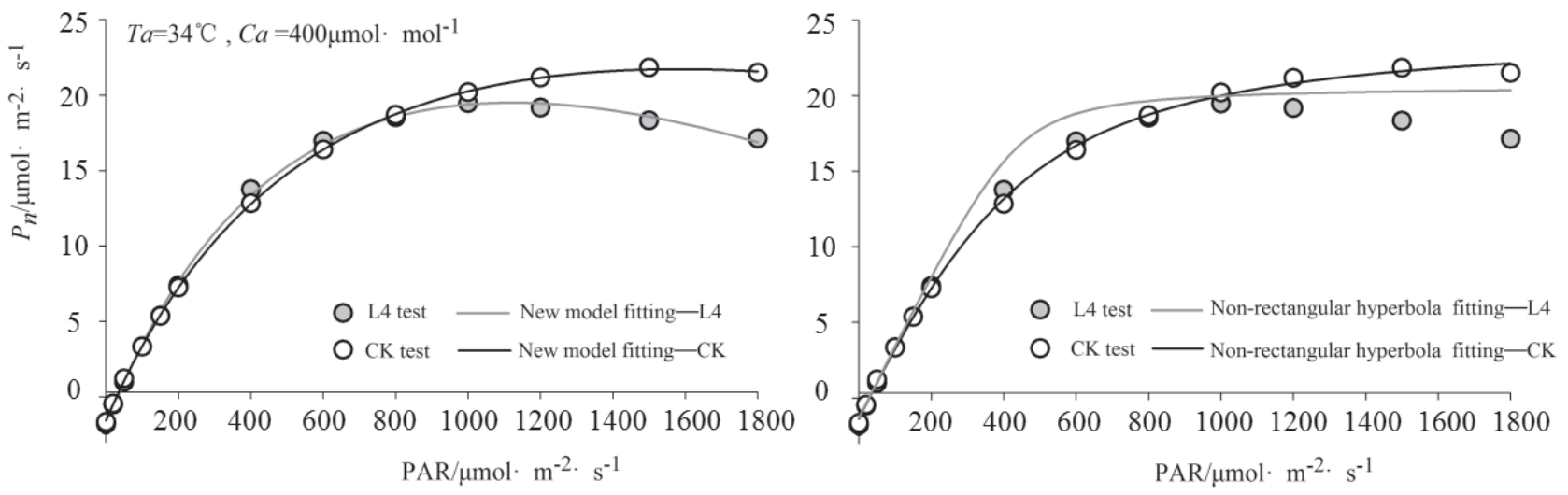

Fig. 4. Simulation results of photosynthetic-light response curve for flooding and control treatment at jointing-booting stage. 
Table 3. Fitting parameters of new photosynthetic-light response model at jointing-booting stage.

\begin{tabular}{|c|c|c|c|c|c|c|c|c|c|}
\hline \multirow{2}{*}{ Treatment } & \multicolumn{3}{|c|}{ Model Parameter } & \multicolumn{3}{c|}{ Characteristic Parameter } & \multicolumn{2}{c|}{ Statistical Parameter } \\
\cline { 2 - 10 } & $\alpha$ & $\beta$ & $\gamma$ & $\mathrm{R}_{\mathrm{d}}$ & $\mathrm{P}_{\max }$ & $\mathrm{L}_{\mathrm{sp}}$ & $\mathrm{L}_{\mathrm{cp}}$ & $\mathrm{R}^{2}$ & SSE \\
\hline L4 & 0.061725 & 0.0002758 & 0.001099 & 1.908649 & 19.5 & 1121.53 & 32.31 & 0.999136 & 0.714888 \\
\hline $\mathrm{CK}$ & 0.055873 & 0.0001671 & 0.001132 & 1.567677 & 21.72 & 1579.02 & 29.12 & 0.99992 & 0.07615 \\
\hline
\end{tabular}

Table 4. Fitting parameters of non-rectangular hyperbolic model at jointing-booting stage.

\begin{tabular}{|c|c|c|c|c|c|c|}
\hline \multirow{2}{*}{ Treatment } & \multicolumn{2}{|c|}{ Model Parameter } & \multicolumn{2}{c|}{ Characteristic Parameter } & \multicolumn{2}{c|}{ Statistical Parameter } \\
\cline { 2 - 7 } & $\alpha$ & $\theta$ & $\mathrm{R}_{\mathrm{d}}$ & $\mathrm{P}_{\max }$ & $\mathrm{R}^{2}$ & SSE \\
\hline L4 & 0.048 & 0.961 & 1.33 & 21.96 & 0.994 & 5.23 \\
\hline CK & 0.049 & 0.732 & 1.387 & 25.809 & 0.999 & 0.924 \\
\hline
\end{tabular}

the light response curve with light suppression. As for the new model, it fit well for both situations above. The characteristic parameter in the non-rectangular hyperbolic model was higher than that in the new model, and the simulation results for the new model were much closer to the measured value. Galmés [29] and Contin [30] found that with the high light intensity at sunny noon, it was prone to have light suppression. With the combination of high light intensity and environmental stress (high temperature or drought), the sensitivity to light suppression could increase, resulting in light suppression under the condition of not too strong light, which was consistent with the results obtained by the new model.

The fitting curve of photosynthetic-light response at heading-flowering and milky stages under water level regulation was shown in Fig. 5, and the parameters were in Table 5. Under the same light intensity, $\mathrm{P}_{n}$ value decreased at the end of water level control both for flooding and drought treatments at the

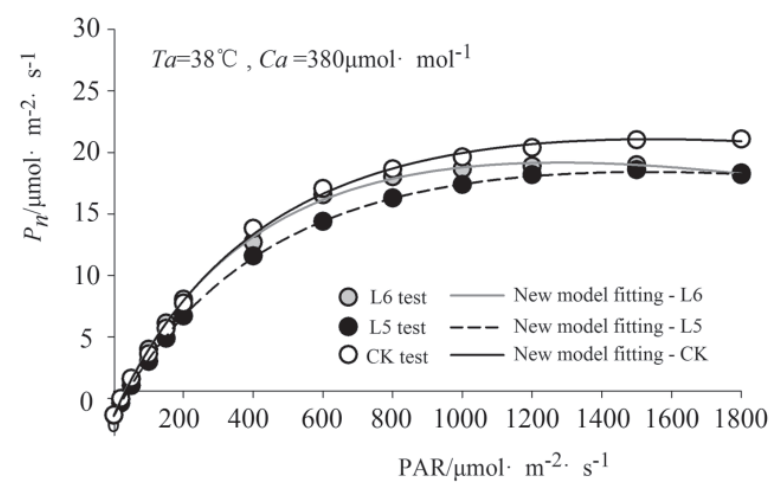

(a) the end of flooding of L5 and L6 treatments

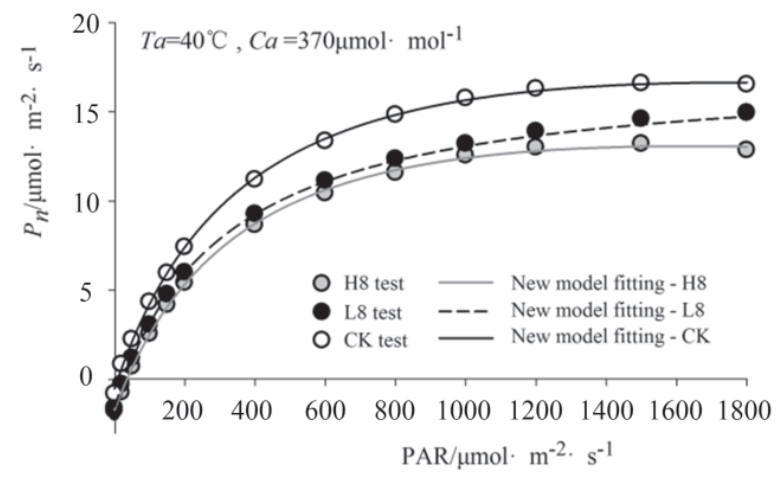

(c) the end of flooding and droughting of L8 and H8

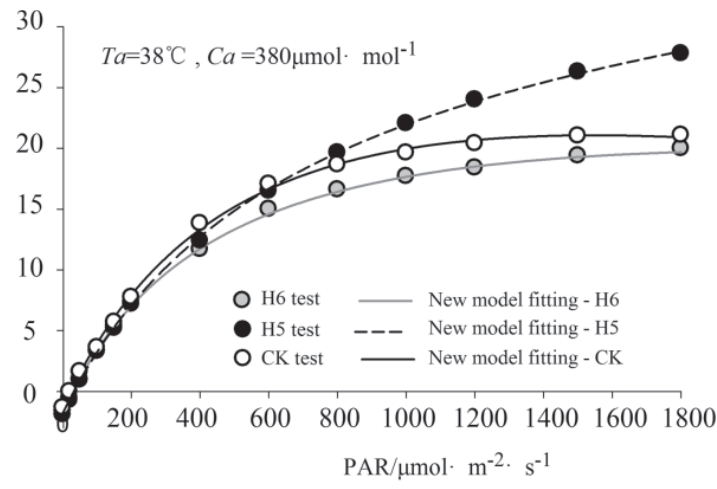

(b) the end of droughting of $\mathrm{H} 5$ and rewatering of $\mathrm{H} 6$

Fig. 5. Fitting curve of photosynthetic light response. 
Table 5. Parameters of photosynthetic-light response model.

\begin{tabular}{|c|c|c|c|c|c|c|c|c|c|c|}
\hline \multirow{2}{*}{$\begin{array}{c}\text { Growth } \\
\text { Stage }\end{array}$} & \multirow{2}{*}{ Treatment } & \multicolumn{3}{|c|}{ New Model Parameter } & \multicolumn{3}{c|}{ Characteristic Parameter } & \multicolumn{2}{c|}{ Statistical Parameter } \\
\cline { 3 - 11 } & & $\alpha$ & $\beta$ & $\gamma$ & $\mathrm{R}_{\mathrm{d}}$ & $\mathrm{P}_{\max }$ & $\mathrm{L}_{\mathrm{sp}}$ & $\mathrm{L}_{\mathrm{cp}}$ & $\mathrm{R}^{2}$ & SSE \\
\hline \multirow{4}{*}{$\begin{array}{c}\text { Heading- } \\
\text { flowering }\end{array}$} & $\mathrm{H} 6$ & 0.061898 & 0.000070 & 0.001951 & 1.718386 & 20.05 & 2239.59 & 29.41 & 0.999640 & 0.282875 \\
\cline { 2 - 12 } & $\mathrm{H} 5$ & 0.057465 & -0.000044 & 0.001529 & 1.776384 & & & 32.21 & 0.999738 & 0.362194 \\
\cline { 2 - 11 } & $\mathrm{L} 6$ & 0.063148 & 0.000198 & 0.001515 & 1.347480 & 19.17 & 1279.76 & 22.15 & 0.999360 & 0.491342 \\
\cline { 2 - 11 } & $\mathrm{CK}$ & 0.053202 & 0.000159 & 0.001374 & 1.428143 & 18.41 & 1528.77 & 28 & 0.999736 & 0.189045 \\
\hline \multirow{3}{*}{ Milky } & $\mathrm{L} 8$ & 0.052873 & 0.000104 & 0.002360 & 1.686762 & 13.08 & 1638.59 & 34.63 & 0.999442 & 0.212245 \\
\cline { 2 - 11 } & $\mathrm{H} 8$ & 0.061408 & -0.000005 & 0.003191 & 1.510599 & & & 26.69 & 0.999892 & 0.045579 \\
\cline { 2 - 11 } & $\mathrm{CK}$ & 0.059164 & 0.000092 & 0.002326 & 0.499873 & 16.65 & 1779.65 & 8.62 & 0.999536 & 0.235432 \\
\hline
\end{tabular}

heading-flowering stage. Referring to drought treatment, the $\mathrm{P}_{n}$ increased obviously with light intensity increasing after rewatering. For two flooding treatments, $\mathrm{P}_{\mathrm{n}}$ for L6 decreased slightly more slowly than that for L5. Furthermore, $\mathrm{P}_{\mathrm{n}}$ for L6 was lower than $\mathrm{CK}$ only when $\mathrm{PAR}>800 \mu \mathrm{mol} \cdot \mathrm{m}^{-2} \cdot \mathrm{mol}^{-1}$, while $\mathrm{P}_{\mathrm{n}}$ for L5 was lower than $\mathrm{CK}$ at a lower light intensity $\left(\right.$ PAR $\left.=200 \mu \mathrm{mol} \cdot \mathrm{m}^{-2} \cdot \mathrm{mol}^{-1}\right)$. This illustrated that under flooding conditions, keeping higher leakage intensity (4 mm/d) was favorable for alleviating the decline of $\mathrm{P}_{n}$ caused by flooding, while lower leakage intensity ( $2 \mathrm{~mm} / \mathrm{d}$ ) might result in waterlogging. At the milky stage, both flooding and drought could result in $\mathrm{P}_{n}$ decreasing under the same light intensity, with a higher reducing range for drought treatment. Milky stage was the key period for grain formation, which needed a certain amount of water supply. However, long-time flooding could result in root hypoxia and lower root system activity, affecting leaf photosynthesis.

\section{Conclusions}

With the comparison of flooding and drought condition, this article conducted research on the difference of the responses of net photosynthetic rate on environmental factors. The following conclusions could be drawn from the above discussion:

1) The $P_{n}$ with a lower leakage amount $(2 \mathrm{~mm} / \mathrm{d})$ decreased slightly more than that with a higher leakage amount $(4 \mathrm{~mm} / \mathrm{d})$, and $\mathrm{P}_{\mathrm{n}}$ under heavy drought treatment $(-600 \mathrm{~mm})$ decreased slightly more than that under light drought treatment $(-400 \mathrm{~mm})$. After rewatering at the tillering stage, $\mathrm{P}_{\mathrm{n}}$ recovered rapidly and showed compensation effect, while it recovered slowly at the jointing-booting stage and was even difficult to recover at the heading-flowering stage. At the milky stage, it was easy to recover.

2) $P_{n}$ exhibited an impact of quadric relationship on PAR and $\mathrm{C}_{\mathrm{i}}$ both in the morning and in the afternoon. $\quad \mathrm{P}_{\mathrm{n}}$ exhibit an impact of quadric relationship on $\mathrm{T}_{\mathrm{a}}$ in the morning, while it showed a linear relationship in the afternoon. $\mathrm{P}_{\mathrm{n}}$ reached peak when PAR was $900 \mu \mathrm{mol} \cdot \mathrm{m}^{-2} \cdot \mathrm{mol}^{-1}$ in the morning for drought treatment, while it decreased not obviously for flooding treatment. $\mathrm{P}_{\mathrm{n}}$ reached its peak at $37^{\circ} \mathrm{C}$ and $35^{\circ} \mathrm{C}$ for flooding and drought treatment, respectively, while it reached peak when the leaf $\mathrm{CO}_{2}$ concentration was $380 \mu \mathrm{mol} \cdot \mathrm{mol}^{-1}$ and $350 \mu \mathrm{mol} \cdot \mathrm{mol}^{-1}$, respectively. Under the same PAR, $\mathrm{C}_{\mathrm{i}}$, or $\mathrm{T}_{\mathrm{a}}, \mathrm{P}_{\mathrm{n}}$ value in the afternoon was lower than that in the morning, performing the characteristic of hysteresis.

3) Both flooding and drought condition could result in $\mathrm{P}_{\mathrm{n}}$ decreasing, aggravating the effect of light suppression of the rice leaves. The photosyntheticlight response curve after rewatering at headingflowering stage showed that $\mathrm{P}_{\mathrm{n}}$ increased rapidly with light intensity increasing after rewatering, showing physiological compensation. Keeping a higher leakage intensity $(4 \mathrm{~mm} / \mathrm{d})$ was favorable for alleviating the decline of $\mathrm{P}_{\mathrm{n}}$ caused by flooding. With the comparison of two model simulation results, the new model fit better on the photosynthetic-light response curve than the non-rectangular hyperbolic model, and simulation results were much more close to measured value.

\section{Acknowledgements}

Our research was financially supported by the National Natural Science Foundation of China (No. 51409124, 51409126, 41401628 and 51679108), the Natural Science Foundation of Jiangsu Province, China (No.BK20140564), Key Laboratory of Efficient Irrigation-Drainage and Agricultural Soil-Water Environment in Southern China(Hohai University), Ministry of Education(2017B20414-2), the High-level Talent Research Project of North China University of Water Resources and Electric Power (No.201705017), and Zhejiang basic public welfare research plan(NO. LGN18E090002). 


\section{Conflict of Interest}

The authors declare that there is no conflict of interest regarding the publication of this paper.

\section{References}

1. MAO Z. Water Saving Irrigation for Rice and Its Effect on Environment. Engineering Science, 4 (7), 8, 2002.

2. XU J.Z., PENG S.Z., YANG S.H., WANG W.G. Ammonia volatilization losses from a rice paddy with different irrigation and nitrogen managements. Agricultural Water Management, 104, 184, 2012.

3. TAN X., SHAO D., LIU H., YANG F., XIAO C., YANG $\mathrm{H}$. Effects of alternate wetting and drying irrigation on percolation and nitrogen leaching in paddy fields. Paddy \& Water Environment, 11 (1-4), 381, 2013.

4. WANG S.L., WANG X.G.., BROWN L.C., QU X. Current status and prospects of agricultural drainage in china. Irrigation and Drainage, 56, 47, 2010.

5. TIAN S., YOUSSEF M.A., SKAGGS R.W., AMATYA D.M., CHESCHEIR G.M. Drainmod-forest: integrated modeling of hydrology, soil carbon and nitrogen dynamics, and plant growth for drained forests. Journal of Environmental Quality, 41, 764, 2012.

6. YU S.E., MIAO Z.M., XING W.G., SHAO G.C., JIANG Y.X. Research advance on irrigation and drainage for rice by using water level as regulation index. Journal of Irrigation and Drainage, 29, 134, 2010.

7. XIAO M.H., YU S.E., SHE D., HU X.J., CHU L.L. Nitrogen and phosphorus loss and optimal drainage time of paddy field under controlled drainage condition. Arabian Journal of Geosciences, 8 (7), 4411, 2015.

8. XIAO M.H., MIAO Z.M., LI Y.Y. Changes of root-zone soil environment in flooded paddy field under controlled drainage conditions. Polish Journal of Environmental Studies, 2, 881, 2017

9. PANDA D., SHARMA S.G., SARKAR R.K. Chlorophyll fluorescence parameters, $\mathrm{CO}_{2}$, photosynthetic rate and regeneration capacity as a result of complete submergence and subsequent re-emergence in rice (Oryza sativa L.). Aquatic Botany, 88 (2), 127, 2008.

10. HIRASAWA T., OZAWA S., TAYLARAN R., OOKAWA $T$. Varietal differences in photosynthetic rates in rice plants, with special reference to the nitrogen content of leaves. Plant Production Science, 13 (1), 53, 2010.

11. HUANG M., SHAN S.L., ZHOU X.F., CHEN J., CAO F.B., JIANG L.G., ZOU Y.B. Leaf photosynthetic performance related to higher radiation use efficiency and grain yield in hybrid rice. Field Crops Research, 193, 87, 2016.

12. JIANG Q., ROCHE D., MONACO T.A., DURHAM S. Gas exchange, chlorophyll fluorescence parameters and carbon isotope discrimination of 14 barley genetic lines in response to salinity. Field Crops Research, 96 (2-3), 269, 2006.

13. KIANI-POUYA A. Changes in activities of antioxidant enzymes and photosynthetic attributes in triticale ( $\times$ triticosecale, wittmack) genotypes in response to long-term salt stress at two distinct growth stages. Acta Physiologiae Plantarum, 37 (4), 1, 2015.

14. MIAO Z.M., YU S.E., LU B., DING J.H., YU Z.H. Relationships of 'water requirement photosynthesis production' for paddy rice using structural equation modeling. Transactions of the Chinese Society of Agricultural Engineering, 29 (6), 91, 2013.

15. WANG W., XIA M.X., CHEN J., YUAN R., DENG F.N., SHEN F.F. Gene expression characteristics and regulation mechanisms of superoxide dismutase and its physiological roles in plants under stress. Biochemistry, 81 (5), 465, 2016.

16. LI Y.S., LI S.S. Effect of submergence stress on the distribution of starch granules in leaf sheath and leaf of rice. Journal of Wuhan Botanical Research, 18 6), 528, 2000.

17. HIRANO T., UCHIDA N., AZUMA T., YASUDA T. Effect of submergence on distribution of photoassimilates and activities of sucrose metabolizing enzymes in sink organs of floating rice. Japanese Journal of Crop Science, 65 (3), 540, 2008.

18. HU J., CAO W., JIANG D., LUO W. Quantification of water stress factor for crop growth simulation i. effects of drought and waterlogging stress on photosynthesis, transpiration and dry matter partitioning in winter wheat. Acta Agronomica Sinica, 30( 4), 315, 2004.

19. LV J., LI C., ZHANG J., LI F. Effect of drought on distribution of carbon assimilation in different genotypes of spring wheat. Agricultural Research in the Arid Areas, 21 (2), 77, 2005.

20. MING D.F., PEI Z.F., NAEEM M.S., GONG H.J., ZHOU W.J. Silicon alleviates peg-induced water-deficit stress in upland rice seedlings by enhancing osmotic adjustment. Journal of Agronomy and Crop Science, 198 (1), 14, 2012.

21. WANG J.Y., JIA J.X., XIONG Z.Q., KHALIL M.A.K., XING G.X. Water regime-nitrogen fertilizer-straw incorporation interaction: field study on nitrous oxide emissions from a rice agroecosystem in nanjing, china. Agriculture Ecosystems and Environment, 141 (3), 437, 2011.

22. TAN X., SHAO D., GU W., LIU H. Field analysis of water and nitrogen fate in lowland paddy fields under different water managements using hydrus-1d. Agricultural Water Management, 150, 67, 2015.

23. HE Y., ZHANG J., XU J., HONG D., YANG S. Regulation and control of water transformation through coupling irrigation and drainage in paddy field. Transactions of the Chinese Society of Agricultural Engineering, 32, 144, 2016.

24. ZHU C.H., ZOU D., YAN F.J., YU P., HUI X.U., SUN Y.J., MA J. Effects of different paddy field drainage degrees and panicle nitrogen fertilizer managements on photosynthetic productivity and nitrogen utilization of rice under triangle-planted system of rice intensification. Acta Agronomica Sinica, 39 (4), 735, 2013.

25. CHAUM S., SAMPHUMPHUANG T., KIRDMANEE C. Glycinebetaine alleviates water deficit stress in indica rice using proline accumulation, photosynthetic efficiencies, growth performances and yield attributes. Australian Journal of Crop Science, 7 (2), 213, 2013.

26. XIA J., ZHANG S., GUO J., RONG Q., ZHANG G. Critical effects of gas exchange parameters in tamarix chinensis, lour on soil water and its relevant environmental factors on a shell ridge island in china's yellow river delta. Ecological Engineering, 76, 36, 2015.

27. HERRICK J.D., THOMAS R.B. Effects of $\mathrm{CO}_{2}$ enrichment on the photosynthetic light response of sun and shade leaves of canopy sweetgum (liquidambar styraciflua) in a forest ecosystem. Tree Physiology, 19 (12), 779, 1999. 
28. YE Z.P., YU Q. Mechanism model of stomatal conductance. Chinese Journal of Plant Ecology, 33 (04), 772, 2009.

29. GALMÉS J., ABADÍA A., MEDRANO H., FLEXAS J. Photosynthesis and photoprotection responses to water stress in the wild-extinct plant lysimachia minoricensis. Environmental \& Experimental Botany, 60 (3), 308, 2007.
30. CONTIN D.R., SORIANI H.H., HERNÁNDEZ I., FURRIEL R.P.M., MUNNÉ-BOSCH S., MARTINEZ C.A. Antioxidant and photoprotective defenses in response to gradual water stress under low and high irradiance in two malvaceae tree species used for tropical forest restoration. Trees, 28 (6), 1705, 2014. 